\title{
Pengaruh Media Semai dan Dosis Biochar terhadap Pertumbuhan Benih Cabai Rawit (Capsicum frutescens L.) di Persemaian
}

\author{
Pianto Ramadhan Prastio ${ }^{1 *}$, Asih Farmia ${ }^{1}$ \\ ${ }^{1}$ Program Studi Teknologi Benih, Jurusan Pertanian, Politeknik Pembangunan Pertanian \\ Yogyakarta-Magelang \\ *Corresponding author: prastio1222@gmail.com
}

\begin{abstract}
Abstrak
Tanaman cabai rawit memiliki potensi ekonomi yang baik untuk dimanfaatkan dalam bisnis karena kebutuhan akan cabai tinggi dengan harga tinggi, sehingga perlunya teknik persemaian yang baik agar benih dapat tumbuh cepat dan seragam dengan menggunakan berbagai media semai. Penelitian ini bertujuan untuk mengetahui pengaruh beberapa media semai dan dosis biochar tempurung kelapa terhadap pertumbuhan benih cabai rawit yang dilakukan di dalam rumah semai di Desa Sembawa kabupaten Banyuasin provinsi Sumatera Selatan pada bulan Maret-Mei 2021. Tujuan penelitian ini adalah untuk mengetahui pengaruh perlakuan dari beberapa jenis media semai dan takaran dosis biochar tempurung kelapa. Metode yang digunakan adalah Rancangan Acak Lengkap (RAL) dengan dua faktor yaitu faktor pertama media semai yang terdiri dari sekam bakar, cocopeat, dan pasir, faktor kedua adalah biochar tempurung kelapa dengan dosis 10 gr, 20 gr, dan 30 gr. Parameter yang diamanti meliputi tinggi kecambah (cm) dan jumlah daun. Dari hasil pengamatan bawah benih cabai rawit (Capsicum frutescens L.) dapat tumbuh pada semua jenis media semai meliputi sekam bakar, cocopeat, dan arang sekam dengan hasil pertumbuhan yang berbeda. Media semai yang baik adalah perlakuan berupa Pasir dengan rata-rata tinggi kecambah 3,721 cmdan rata-rata jumlah daun 2,966 helai berdeda nyata dengan perlakuan (M2) cocopeat, (M1) sekam bakar dan Kontrol, sedangkan untuk pemberian biochar tidak berbeda nyata pada tinggi tanaman dan jumlah daun.
\end{abstract}

Kata Kunci : Benih cabai rawit, Biochar tempurung kelapa, Media semai

\section{Abstract}

Cayenne pepper plants have a good economic potential for good commercial use because of the need for high peppers at high prices, so they need good ape-purchase techniques to make the seed grow quickly and uniform in various media. The study was aimed at recognizing the impact of some semai media and a dose of coconut biochar against the growing of cayenne pepper seeds in the Sembawa, Banyuasin district of south Sumatra province in march-may 2021. The purpose of this study is to know the effects of treatment of someseedling media and a dose of coconut biochar. The method used is a complete fragmentary design (RAL) with the first factors of the seedling consisting of burnt chaff, cocopeat, and sand, the second factor is coconut biochar with a dose are $10 \mathrm{gr}, 20 \mathrm{gr}$, and $30 \mathrm{gr}$. Parameters covering a height (cm) and number of leaves. The results of the examination under the cayid plant seed (Capsicum Frutescens L.) can grow on all types of media over the burnt chaff, cocopeat, and charcoal husks with different growth results. Good seedling media is the treatment of sand with an average growth is $3.721 \mathrm{~cm}$ and an average number of leaves are 2.966 sheet, actual different with the treatment (M2) cocopeat, (M1) of burnt chaff and control whereas for giving biochar is not real different in plant height and number of leaves.

Keywords: Cayenne pepper seed, Coconut shells biochar, Seedling media 
Prosiding Seminar Nasional Pembangunan dan Pendidikan Vokasi Pertanian

Politeknik Pembangunan Pertanian Manokwari, 31 Juli 2021

e ISSN : 2774-1982

DOI : https://doi.org/10.47687/snppvp.v2i1.184

\section{PENDAHULUAN}

Cabai rawit (Capsicum frutescens L.) merupakan komoditas sayuran yang cukup stategis, pada musim tertentu kenaikan harga cabai cukup signifikan sehingga mempengaruhi tingkat inflasi. Fluktuasi harga ini terjadi hampir setiap tahun dan meresahkan masyarakat. Produktivitas harus ditingkatkan untuk mengurangi permintaan cabai di pasar yang semakin meningkat seiring dengan pertumbuhan penduduk.

Tanaman cabai rawit memiliki potensi ekonomi yang baik untuk dimanfaatkan dalam bisnis karena pertumbuhan akan cabai tinggi dengan harga tinggi. Harga cabai rawit dapat berubah setiap saat apabila pasokan cabai sedikit dengan jumlah yang selalu tinggi sehingga menyebabkan harganya naik. Menurut outlook Direktorat Jenderal Tanaman Pangan (2016) terjadi peningkatan produksi benih cabaai nasional 843.998 ton di tahun 2016 menjadi 887.260 ton pada tahun 2007.

Peningkatan produktivitas harus seimbang antara peningkatan kualitas dan kuantitas dari cabai tersebut. Peningkatan produksi cabai setiap tahun harus dijaga kesetabilannya. Berdasarkan data statistik (2018), bahwa total produksi cabai nasional khususnya cabai rawit mengalami peningkatan dari tahun 2013 sampai 2018. Dalam suatu sistem budidaya benih memegang peranan yang sangat penting, benih bermutu merupakan faktor utama suksesnya produksi di bidang pertanian (Wiguna, 2013). Salah satu indikator benih bermutu adalah memiliki viabilitas dan vigor yang baik. Benih yang memiliki viabilitas dan vigor yang baik akan mampu bertahan dan berkecambah serta menghasilkan tanaman yang tumbuh baik dilapangan yang beragam dan luas (Wartapa et al., 2009; Peluang et al., 2014).

Dalam kegiatan budidaya, media merupakan salah satu faktor penting untuk menunjang keberhasilan. Media tanam merupakan bahan yang digunakan untuk pembibitan yang berfungsi sebagai penyimpanan unsur hara atau nutrisi, mengantur kelembaban dan suhu udara serta berpengaruh terhadap proses pembentukan akar. (Putri, et al., 2013)

Media tanam sangat berperan penting dalam melakukaan budidaya tanaman salah satunya dalam melakukan persemaian, karena dapat mempengaruhi daya berkecambah dan pertumbuhan benih tersebut. Menurut Farmia (2020), media tanam cocopeat dan dosis serbuk cangkang telur 20 gr dan perlakuan cocopeat dengan serbuk cangkang telur $10 \mathrm{gr}$ memberikan hasil yang tertinggi dalam pertumbuhan microgreen brokoli, hasil media tanam yang terbaik jika diperlakukan sendiri-sendiri adalah media tanam cocopeat. 
Prosiding Seminar Nasional Pembangunan dan Pendidikan Vokasi Pertanian

Politeknik Pembangunan Pertanian Manokwari, 31 Juli 2021

e ISSN : 2774-1982

DOI : https://doi.org/10.47687/snppvp.v2i1.184

Sebagian besar unsur- unsur hara yang dibutuhkan tanaman disediakan melalui media tanam, selanjutnya diserap oleh perakaran dan digunakan untuk proses fisiologi tanaman (Ermina, 2010). Pada prinsipnya suatu media tumbuh harus mempunyai empat fungsi pokok untuk memberikan pertumbuhan yang baik bagi tanaman, yaitu harus dapat menahan air tersedia, menyimpan hara bagi tanaman, menunjang tanaman dan mempunyai aerasi yang baik.

Media tanam yang umum digunakan adalah tanah, karena didalam tanah tersedia faktor-faktor utama untuk pertumbuhan tanaman seperti unsur hara, air, dan udara (Ningrum, 2010). Akan tetapi menurut Isroi (2009), kondisi tanah sekarang semakin mengalami penurunan karena rendahnya bahan organik. Seperti penelitian yang dilakukan oleh Farmia. A. (2020) tentang pengaruh beberapa media tanam dan dosis serbuk cangkang telur ayam terhadap pertumbuhan microgreen brokoli (Brassica oleracea var. Intalica Planck).

Selain tanah bisa menggunakan media alternatif lainya seperti, sekam bakar, cocopeat, dan pasir dalam melakukan persemaian, Karena media alternatif ini memiliki kelebihan sendiri-sendiri di dalam proses persemaian. Media cocopeat memiliki pori mikro yang mampu menyerap gerakan air yang lebih besar sehingga menyebabkan ketersediaan air yang lebih tinggi (Istomo dan Valentino, 2012). Conover (1980) sekam padi memiliki aerasi dan drainasi yang baik, tetapi masih mengandung organismeorganisme pathogen atau organisme yang menghambat pertumbuhan tanaman. Pasir sering digunakan sebagai media alternatif untuk menggantikan fungsi tanah. Namun pasir memiliki pori-pori berukuran besar (pori-pori makro), substitusi atau penambahan bahan organik yang bersifat menahan air dapat memperbaiki sifat pasir tersebut.

Penambahan arang biochar ke lahan pertanian memberikan keuntungkan antara lain berpengaruh terhadap ketersediaan hara, retensi hara, dan kemampuan menyimpan atau menahan air tanah, sulit terdegradasi mikroorganisme tanah (Glaser et al., 2002). Biochar dapat dibuat dari limbah pertanian, seperti tempurung kelapa, kulit buah kakao, sekam, dan seresah tanaman. Biochar merupakan bahan organik tahan pelapukan seperti yang dilaporkan para pakar akhir-akhir ini (Lehmann et al., 2003). Biochar merupakan bahan yang berwarna hitam yang kaya karbon yang memiliki ketahanan yang tinggi terhadap dekomposisi dan mineralisasi karena karbon di dalam biochar dalam bentuk seyawa aromatik (Schmidt et al., 2001). Beberapa penelitian telah menunjukkan bahwa biochar mampu meningkatkan kesuburan dan produktivitas tanah (Lehmann et al., 2003). 
Prosiding Seminar Nasional Pembangunan dan Pendidikan Vokasi Pertanian

Politeknik Pembangunan Pertanian Manokwari, 31 Juli 2021

e ISSN : 2774-1982

DOI : https://doi.org/10.47687/snppvp.v2i1.184

Menurut Cayanti (2006) menanam cabai dengan media yang berbeda akan menghasilkan kualitas tanaman cabai yang berbeda pula. Dalam penelitiannya yang berjudul "Pengaruh media terhadap Kualitas Cabai Hias (Capsicum sp.) dalam pot. Media yang digunakan adalah: sekam:tanah:pupuk kandang (M1), serbuk gergaji: tanah: pupuk kandang (M2), dan kokopit: tanah: pupuk kandang (M3). Berdasarkan latar belakang tersebut, maka peneliti ingin melakukan penelitian dengan media semai dan dosis biochar yang berbeda agar mengetahui media semai mana yang lebih baik digunakan untuk melakukan penyemaian benih cabai rawit (Capsicum frutescens L.). Sampai saat ini masih belum banyak penelitian yang menggunakan serbuk biochar tempurung kelapa pada media semai benih cabai rawit (Capsicum frutescens L.). Sekarang ini tempurung kelapa masih belum dimanfaatkan dengan optimal dikalangan masyarakat dan hanya menjadi limbah dibidang pertanian. Melihat penjelasan diatas maka dilakukan penelitian dengan judul judul "Pengaruh Media Semai dan Dosis Biochar terhadap Pertumbuhan Benih Cabai Rawit (Capsicum frutescens L.) di Persemaian".

\section{METODE}

Penelitian ini dilakukan pada rumah semai di Desa Sembawa, Kabupaten Banyuasin, Provinsi Sumatera Selatan. Kegiatan penelitian ini dilakukan dari April - Juni 2021. Alat yang digunakan pada penelitian ini yaitu, 1) nampan plastik, 2) pinset, 3) timbangan digital, 4) plastik, 5) sekop kecil, 6) spayer tangan, 7) penggaris. Bahan yang digunakan dalam penelitian ini yaitu, 1) tanah, 2) sekam bakar, 3) pasir, 4) cocopeat, 5) benih cabai rawit, 6) Biochar tempurung kelapa 7) paranet 8) waring 9) air.

Penelitian ini menggunakan Rancangan Acak Lengkap (RAL) dua faktor, faktor pertama berupa media semai (M) yang terdiri dari tiga taraf yaitu : M1 (sekam bakar), M2 (cocopeat), dan M3 (pasir) dan faktor kedua yaitu dosis biochar tempurung kelapa dengan tiga taraf yaitu : 10 gr (B1), 20 gr (B2), dan 30 gr (B3). Sehingga didapatkan 9 kombinasi perlakuan Analisa dalam penelitian ini menggunakan Analysis of variance atau Anova. Jika dari hasil perhitungan ada pengaruh maka dimana $\mathrm{F}$ hitung $>\mathrm{F}$ tabel akan dilakukan uji lanjut dengan menggunakan uji DMRT. Parameter yang dihitung dalam penelitian ini adalah tinggi tanaman yang diukur dengan mengukur tinggi tanaman benih cabai pada awal titik tumbuh, dan menghitung jumlah daun yang dihitung dari daun pertama berkecambah. Dari setiap ulangan diambil 5 sampel tanaman dari masing- masing nampan. 
Prosiding Seminar Nasional Pembangunan dan Pendidikan Vokasi Pertanian

Politeknik Pembangunan Pertanian Manokwari, 31 Juli 2021

e ISSN : 2774-1982

DOI : https://doi.org/10.47687/snppvp.v2i1.184

\section{HASIL DAN PEMBAHASAN}

\section{Hasil}

Dari hasil uji Anova menunjukan bahwa media semai memberikan pengeruh nyata pada tinggi tanaman benih cabai karena $\mathrm{F}$ Hitung > F tabel untuk mengetahui pengaruh yang signifikan pada perlakuan untuk tinggi tanaman dilanjutkan dengan uji Duncan dengan taraf $(0,05)$ yang disajikan pada tabel 1 .

Tabel 1. Hasil Uji Duncan 5\% Media Semai pada Tinggi Tanaman

\begin{tabular}{ll}
\hline Perlakuan & Tinggi Tanaman \\
\hline Kontrol & $1,947^{\mathrm{a}}$ \\
M1 & $2.9543^{\mathrm{b}}$ \\
M2 & $1,334^{\mathrm{a}}$ \\
M3 & $3,3753^{\mathrm{b}}$ \\
\hline
\end{tabular}

Keterangan: Angka yang diikuti huruf yang sama pada kolom yang sama menunjukan tidak ada beda nyata pada uji Duncan 5\%.

Hasil Analisa data dengan Uji DMRT taraf 0,05 (Tabel 1) menunjukan bahwa dari perlakuan tunggal media tanam, ternyata media tanam M3 yaitu pasir memberikan pengaruh hasil terbaik pada tinggi tanaman yang tertinggi yaitu 3,375, sedangkan kontrol memberikan hasil yang terendah pada persemaian yaitu 1,947 tanaman cabai rawit.

Tabel 2. Hasil Uji Duncan 5\% Media Semai pada Jumlah Daun

\begin{tabular}{ll}
\hline Perlakuan & Jumlah Daun \\
\hline Kontrol & $2,3^{\mathrm{a}}$ \\
M1 & $2,4133^{\mathrm{b}}$ \\
M2 & $1,33^{\mathrm{a}}$ \\
M3 & $2,966^{\mathrm{b}}$ \\
\hline
\end{tabular}

Keterangan: Angka yang diikuti huruf yang sama pada kolom yang sama menunjukan tidak ada beda nyata pada uji Duncan 5\%.

Hasil analisa data denganUji DMRT taraf 0,05 (Tabel 2) menunjukan bahwa dari perlakuan tunggal media tanam. Ternyata media tanam M3 yaitu pasir memberikan pengaruh terbaik untuk jumlah daun yaitu 2,96 yang paling banyak, sedangkan perlakuan M2 yaitu media cocopeat memberikan hasil yang jumlah daun paling sedikit pada persemaian tanaman cabai rawit.

Tabel 3. Hasil Uji Duncan 5\% Pengaruh Biochar pada Pertumbuhan Tanaman Cabai

\begin{tabular}{lll}
\hline Perlakuan & Tinggi Tanaman $(\mathrm{cm})$ & Jumlah Daun \\
\hline Kontrol & $1,947^{\mathrm{a}}$ & $2,3^{\mathrm{a}}$ \\
B1 & $2,8566^{\mathrm{a}}$ & $2,2566^{\mathrm{a}}$ \\
B2 & $2,6083^{\mathrm{a}}$ & $2,1533^{\mathrm{a}}$ \\
B3 & $2,1986^{\mathrm{a}}$ & $1,93^{\mathrm{a}}$ \\
\hline
\end{tabular}

Keterangan: Angka yang diikuti huruf yang sama pada kolom yang sama menunjukan tidak berbeda nyata pada uji Duncan 5\% 
Prosiding Seminar Nasional Pembangunan dan Pendidikan Vokasi Pertanian Politeknik Pembangunan Pertanian Manokwari, 31 Juli 2021

e ISSN : 2774-1982

DOI : https://doi.org/10.47687/snppvp.v2i1.184

Dari hasil Uji DMRT taraf 0,05 (Tabel 3) menunjukan bahwa dari perlakuan tunggal media semai. Biochar, ternyata perlakuan biochar sebanyak 10 gr yaitu B1 memberikan pengaruh terbaik untuk jumlah daun tanaman yang paling banyak dengan angka 2,256, sedangkan perlakuan B3 yaitu dengan dosis 30 gr memberikan hasil jumlah daun paling sedikit yaitu 1,93, terendah pada persemaian tanaman cabai rawit tidak ada beda nyata pada kontrol tanaman paling tinggi dengan angka 2,856 pada perlakuan biochar 10 gr sedangkan tanaman yang terpendek adalah B3 dengan dosis $30 \mathrm{gr}$ dengan angka tinggi tanaman 2,1986. Sedangkan semua dosis perlakuan biochar dan kontrol juga tidak menunjukan beda nyata. Untuk angga jumlah daun paling tinggi pada media kontrol yaitu 2,3 sedangakan perlakuan B3 menunjukan jumlah daun dengan angka yang paling rendah yaitu 1,93 .

Tabel 4. Hasil Uji Duncan 5\% Interaksi Perlakuan Media Semai dengan Dosis Biochar

\begin{tabular}{lll}
\hline Perlakuan & Tinggi Tanaman $(\mathrm{cm})$ & Jumlah Daun \\
\hline Kontrol & $1,947(\mathrm{abc})$ & $2,3(\mathrm{a})$ \\
M1B1 & $3,356(\mathrm{de})$ & $2,53(\mathrm{a})$ \\
M1B2 & $2,891(\mathrm{de})$ & $2,38(\mathrm{a})$ \\
M1B3 & $2,616(\mathrm{~cd})$ & $2,33(\mathrm{a})$ \\
M2B1 & $1,692(\mathrm{abc})$ & $1,5(\mathrm{a})$ \\
M2B2 & $1,47(\mathrm{a})$ \\
M2B3 & $1,213(\mathrm{ab})$ & $1,02(\mathrm{a})$ \\
M3B1 & $1,097(\mathrm{a})$ & $2,74(\mathrm{a})$ \\
M3B2 & $3,522(\mathrm{de})$ & $2,61(\mathrm{a})$ \\
M3B3 & $3,721(\mathrm{de})$ & $2,44(\mathrm{a})$ \\
\hline
\end{tabular}

Keterangan: Angka yang diikuti huruf yang sama pada kolom yang sama menujukan tidak berbeda nyata pada uji Duncan 5\%.

Hasil perhitungan analisis dengan Uji DMRT taraf 0,05 (Tabel 4) menunjukan bahwa perlakuan M3B2 yaitu media tanam pasir dengan penambahan biochar 20 gram memberikan hasil yang terbaik pada tinggi tanaman tinggi $3,721 \mathrm{~cm}$ sedangkan kombinasi perlakuan M2B3 memberikan hasil yang paling rendah yaitu 1,097 cm . Pada semua kombinasi perlakuan tidak ada beda di anatar perlakuan pada jumlah daun di persemaian cabai rawit semua rata-rata berjumlah 2 helai daun.

\section{Pembahasan}

Dari perlakuan media tanam secara tunggal menunjukan hasil bahwa tidak ada beda nyata antara perlakuan M1 dan M3 tetapi berbeda nyata pada M2 dari perlakuan yang terbaik untuk parameter rata-rata tinggi tanaman pada media semai pasir, dan perlakauan secara tunggal media semai menunjukan hasil bahwa tidak ada beda nyata antara perlakuan M1 dan M3 tetapi berbeda nyata pada M2 dari perlakuan yang terbaik 
Prosiding Seminar Nasional Pembangunan dan Pendidikan Vokasi Pertanian

Politeknik Pembangunan Pertanian Manokwari, 31 Juli 2021

e ISSN : 2774-1982

DOI : https://doi.org/10.47687/snppvp.v2i1.184

untuk parameter rata-rata jumlah daun yaitu pada media semai pasir. Hal ini Sejalan dengan penelitian Soeharyo (2005) juga menyatakan bahwa perbandingan media pasir:kascing 1:1 memberikan pengaruh nyata dan menghasilkan pertumbuhan yang terbaik pada tanaman Hygrophila sp. Selain itu pasir juga dapat digunakan sebagai media priming sebagaimana yang disampaikan oleh Erinnovita et al. (2008), yang menyatakan bahwa perlakuan invigorasi, masing-masing perlakuan priming dengan pasir dan perlakuan perendaman air merupakan metode yang efektif dan disarankan untuk memperbaiki perkecambahan benih kacang panjang pada kondisi cekaman salinitas.Menurut $\mathrm{Hu}$ et al. (2006) pasir dapat menjadi media priming yang mampu meningkatkan perkecambahan benih dan pertumbuhan kecambah alfaalfa pada kondisi cekaman salinitas. Tanah berpasir sering dipakai sebagai media dalam bercocok tanam karena memiliki drainase yang baik sehingga media cepat kering, ini disebabkan karena pasir mampu menciptakan ruang pori media yang cukup besar.

Dari analisa data untuk perlakuan biochar ini tidak memberikan pengaruh pada pertumbuhan rata-rata tinggi tanaman dan rata-rata jumlah daun, semua perlakuan memberikan hasil yang sama pada tinggi tanaman dan jumlah daun. Salah satu teknologi tepat guna yang dapat dilakukan adalah dengan memberikan bahan pembenah tanah (soil ameliorant) yang dapat meningkatkan produktivitas tanah dan kandungan karbon (C) organik tanah dalam jangka waktu yang lama. Seperti yang dilaporkan (Mulyati et al., 2014) melaporakna bahwa bahan pembenah tanah yang dapat digunakan adalah biochar atau charcoal (arang hitam) yang merupakan hasil proses pemanasan biomassa organik pada keadaan oksigen terbatas yang dibuat dari berbagai limbah pertanian, seperti batang tembakau, tempurung kelapa, sekam padi tongkol jagung dan lain-lain. Biochar dapat digunakan sebagai alternatif pembenah tanah dan dapat meningkatkan kualitas kesuburan tanah. Bahan ini tidak mudah termineralisasi atau dapat bertahan dalam jangka waktu yang lebih lama, memiliki sifat rekalsitran atau stabil terhadap oksidasi dan lebih stabil di dalam tanah sehingga memiliki pengaruh jangka panjang dalam memperbaiki dan mempertahankan kualitas tanah seperti C organik tanah dan KTK (Steiner et al., 2007; Busscher et al., 2009).

Dalam penelitian ini ternyata perlakuan kontrol memberikan hasil berbeda dengan perlakuan biochar. Kontrol yaitu tanah sudah mengandung bahan organik yang dibutuhkan oleh tanaman. Sedangkan hal ini biochar sebagai bahan memperbaiki tanah. Menurut Lehmann (2007), Aplikasi arang hayati atau Biochar memberikan opsi untuk 
Prosiding Seminar Nasional Pembangunan dan Pendidikan Vokasi Pertanian

Politeknik Pembangunan Pertanian Manokwari, 31 Juli 2021

e ISSN : 2774-1982

DOI : https://doi.org/10.47687/snppvp.v2i1.184

menigkatkan ketersediaan bahan organik tanah dalam jangka waktu panjang, aplikasi biochar sebagai bahan pembenah. Pernyataan Badron dan Tius (2008), pemberian unsur $\mathrm{N}$ dan bahan organik biochar berbahan dasar tempurung kelapa relatif mampu memberikan hasil yang baik pada fase vegetatif. Pemberiaan biochar tidak memberikan efek terhadap tinggi tanaman dan jumlah daun diduga karena tanaman masih pada fase perkecambahan dan juga penggunaan biochar dengan takaran dosis yang rendah, sehingga dalam kajian ini peran biochar saat ini belum efektif, menurut Sukartono (2011), aplikasi biochar lebih efektif digunakan karena pelapukan atau dekomposisinya sangat lambat dan bertahan lama (3 tahun bahkan lebih) dibandingkan bahan organik segar seperti kompos dan pupuk kandang. Seperti yang diketahui biochar sebagai pembenah tanah mengandung $\mathrm{C}$ organik dan sehingga berfungsi memperbaiki tanah seperti pasir. Secara fisiologis dapat berpengaruh pada tinggi tanaman dan jumlah daun untuk dosis biochar yang lain akan dikaji pada penelitian selajutnya.

Kombinasi interaksi perlakuan melihat hasil analisa diduga ketiga media semai ini memiliki kelebihan masing-masing seperti yang telah disebutkan sebelumnya. sehingga ketiga media ini memberikan hasil yang baik bila dikombinasikan dengan beberapa dosis biochar tempurung kelapa untuk parameter tinggi tanaman. Dari hasil analisa pada uji Duncan 0,05 terlihat memberikan hasil yang terbaik yaitu kombinasi perlakuan M3B1. Secara efisiensi 10 gr sudah memberikan hasil yang terbaik sedangkan dengan penambahan biochar kombinasi perlakuan M3B2 memberikan hasil yang terbaik pada tinggi tanaman. Perlakuan pasir dengan berat rata-rata pasir $1,7 \mathrm{~kg} /$ nampan dengan kombinasi biochar dapat memperbaiki kondisi pasir dengan bertambahnya karbon (C) organik memberikan hasil terbaik pada tinggi tanaman cabai di persemaian. $\mathrm{C}$ organik dapat berperan sebagai penyuplay Karbon yang diperlukan dalam proses fotosintesis sehingga proses fotosintesis meningkat, sedangkan $\mathrm{Ca}$ berperan penting menjadi bagian dari struktur sel yaitu dinding dan membran sel dan diperlukan dalam pembentukan atau pembelahan sel-sel baru yang terdapat benang-benang (spindles) miosis (Havlin et al. 2005). Penambahan sub soil, arang tempurung kelapa dan interaksi keduannya pada media tanah bekas tambang pasir memberikan pengaruh positif terhadap pertumbuhan semai jabon, ternyata hasil dari analisa kombinasi penambahan 20 gr arang tempurung kelapa dan 500 gr sub soil menunjukan pertumbuhan semai jabon yang terbaik (Wasis dkk., 2015). 
Prosiding Seminar Nasional Pembangunan dan Pendidikan Vokasi Pertanian

Politeknik Pembangunan Pertanian Manokwari, 31 Juli 2021

e ISSN : 2774-1982

DOI : https://doi.org/10.47687/snppvp.v2i1.184

\section{KESIMPULAN DAN SARAN}

\section{Kesimpulan}

Benih cabai rawit dapat tumbuh pada berbagai media semai alternatif yang dapat digunakan dalam pernyemaian. Pada perlakuan berbagai media semai dan dosis biochar tempurung kelapa menunjukan perlakuan yang paling baik pada media pasir dengan ratarata tinggi tanaman $3,3753 \mathrm{~cm}$ dan rata-rata jumlah daun 2,966 helai pada pertumbuhan benih cabai rawit,sedangkan perlakuan media sekam bakar dapat lebih baik dibandingkan dengan media cocopeat. untuk penambahan dosis biochar tidak berpengaruh nyata terhadap pertumbuhan tinggi tanaman dan jumlah daun benih cabai rawit di persemaian.

\section{Saran}

Berdasarkan pengkajian dari hasil penelitian penulis memberikan saran untuk pengembangan penelitian yaitu perlunya dilakukan penelitian lebih lanjut dengan menggabungkan berbagai media semai dan penggunaan dosis biochar tempurung kelapa untuk pertumbuhan benih cabai rawit serta perlunya dilakukan penelitian lebih dalam untuk percobaan berbagai benih selain benih cabai rawit.

\section{DAFTAR PUSTAKA}

Badan Pusat Statistik. (2018). Produksi tanaman sayuran, accessed September 22, 2020, from https://www.bps.go.id/site/resultTab

Badron, S. \& S. Tius. (2008). Mobilitas Pupuk anorganik N dan P. http:ww.Unhas.ac.id/lemlit/researches/vieuw/320.html (10 Juni 2021)

Cahyono, B. (2007). Cabai Rawit. Kanisius. Yogyakarta.

Chan, K.Y., van Zwieten, B.L., Meszaros, I., Downie, D. \& Joseph, S. (2008). Using poultry litter biochars as soil amendment. Australian Journal of Soil Research,45,437-444.

Cayanti, R.E.O. (2006). Pengaruh Media Terhadap Kualitas Cabai Hias (Capsicum sp.) dalam pot. Skripsi. Fakultas Pertanian. Institut Pertanian Bogor

Conover, C.A. (1980). Foliage Plant. In. R.A. Larson (Ed): Intodution to floriculture. Academic Press. Inc. New york. 607.

Erinnovita, S.M. \& Guntoro. D. (2008). Invigorasi Benih untuk Memperbaiki Perkecambahan Kacang Panjang (Vigna unguiculata Hask. ssp. sesquipedalis) pada Cekaman Salinitas. Fakultas Pertanian. Institut Pertanian Bogor.

Ermina, Y. (2010). Media Tanam Hidroponik dari Arang Sekam. Balai Besar Pelatihan Pertanian (BBPP Lembang). 
Prosiding Seminar Nasional Pembangunan dan Pendidikan Vokasi Pertanian

Politeknik Pembangunan Pertanian Manokwari, 31 Juli 2021

e ISSN : 2774-1982

DOI : https://doi.org/10.47687/snppvp.v2i1.184

Farmia, A. (2020). Pengaruh Beberapa Macam Media Tanam dan Dosis Serbuk Cangkang Telur Ayam terhadap Pertumbuhan Microgreen Brokoli (Brassica oleracea var. Italica Planck). Prosiding Seminar Nasional Pembangunan dan Pendidikan Vokasi Pertanian Politeknik Pembangunan Pertanian Manokwari, 14 November 2020. E ISSN : 2774-1982. P: 31-37.

Glaser, B., J. Lehmann \& W. Zech. (2002). Ameliorating physical and chemical properties of highly weathered soils in the tropics with charcoal -A review. Biol \& Fertility of Soils 35, 219-230.

Havlin, J.L., J.D. Beatonand, \& S.L. Nelson. (2005). Soil Fertility and Fertilizer. An Introduction to Nutrient Management. New Jersey : Pearson Prentice hall.

Hu, J., X. J. Xie, \& W.J. Song. (2006). Sand priming improves alfalfa germination under high-salt concentration stress. Seed Sci. and Technol. 34:199-204.

Isroi. (2009). Pupuk Organik Granul Sebuah Petunjuk Praktis. http://Isroi.wordpress.com, diakses pada tanggal 12-12-2020

Istomo \& Valentino, N. (2012). Pengaruh Perlakuan Kombinasi Media Terhadap Pertumbuhan Anakan Tumih (Combretocarpus rotundatus Miq. Danser). Jurnal Silvikultur Tropika 3(2): 81-84.

Lehmann, J. \& M. Rondon (2005). Bio-char soil managementon highly-weathered soils in the humid tropics. In: N. Uphoff (ed.), Biological Approaches to Sustainable Soil Systems, Boca Raton, CRC Press.

Lehmann, J. \& S. Joseph (2009). Biochar for Environmental Management: Science and Technology. Earthscan-UK. p, 71 - 78.

Lehmann, J. (2007). Bionergy in the black Frontiers in Ecology and the Environment vol. 5, hal 381-387.

Lehmann, J., J.P. da Silva, C. Steiner, T. Nehls, W. Zech, \& B. Glaser. (2003). Nutrient availability and leaching in an archaeological Anthrosol and a Ferralsol of the Central Amazon basin: feltilizer, manure and charcoal amendments. Plant and Soil 249:343-357.

Mulyati, A.B. Baharuddin, S. Tejowulan, \& Muliatiningsih. (2014). Penggunaan Biochar Limbah Pertanian Sebagai Bahan Pembenah Tanah (Soil Ameliorant) untuk Meningkatkan Produktivitas Lahan pada Tanaman Kedelai. Disampaikan pada Seminar Nasional Pengelolaan Lahan Terdegradasi. Pada tanggal 5 Maret 2014. Di Mataram.

Ningrum, F.G.K. (2010). Efektivitas Air Kelapa dan Ampas Teh Terhadap Pertumbuhan Tanaman Mahkota Dewa (Phaleria macrocarpa) pada Media Tanam yang Berbeda. Skripsi. Program Studi Pedidikan Biologi Fakultas Keguruan dan Ilmu Penddikan Universitas Muhammadiyah Surakarta.

Putri, A. D., Sudiarso, \& Islami, T. (2013). Pengaruh Komposisi Media Tanam pada Ternik Bud Chip Tiga Varietas Tebu (Saccharum officinarum L.). Jurnal Produksi Tanaman. 
Prosiding Seminar Nasional Pembangunan dan Pendidikan Vokasi Pertanian

Politeknik Pembangunan Pertanian Manokwari, 31 Juli 2021

e ISSN : 2774-1982

DOI : https://doi.org/10.47687/snppvp.v2i1.184

Schmidt, M.W.I., Skjemstad J.O., Czimczik C.I., Glaser B., Prentice K.M., Gelinas Y. \& Kuhlbusch T.A.J. (2001). Comparative analysis of black carbon in soils. Global Biogeochemical Cycles 15:163-167.

Sekretaris Jenderal Kementerin Pertanian. (2016). Outlook Sub Sektor Komoditas Pertanian Sub Sektor Hortikultura. Pusat Data dan Sistem Informasi Pertanian Kementerin Pertanian 2016.

Setiawati, W., R. Murtiningsih, G.A. Sophadan, \& T. Handayani. (2007). Budidaya Tanaman Sayuran. Balai Penelitian Tanaman Sayuran. Bandung.

Soeharyo, D.C. (2005). Uji Berbagai Perbandingan Medi Pasir dan Kompos Terhadap Pertumbuhan dan Kualitas Hygrophila sp. Fakultas Pertanian Universitas Kristen Satya Wacana, Salatiga.

Steiner, C., W.G. Teixeris, \& J. Lehman. (2007). Long Term Effectof Manure, Charcoal and Mineral Fertilization on Crop Production and Fertilityon a Highly Wearthered Central Amazonian Upland Soil. Plant Soil 291: 257-290.

Steiner, C. (2007). Soil charcoal amendments maintain soilfertility and establish carbon sink-research and prospects. Soil Ecology Res Dev, 1 -6.

Sukartono. (2011). Pemanfaatan Biochar Sebagai Bahan Amendemen Tanah Untuk Meningkatkan Efisiensi Penggunaan Air dan N Tanaman Jagung (Zea mays) Di Lahan Kering Lombok Utara. Universitas Brawijaya. Malang.

Susila, D.A., Tisna, P., \& Palada. (2012). Improving Management Practices for Transplant Production of Chili Pepper (Capsicum annuum L.), Vegetable Agroforestry System in Indonesia, ICRAF Special Publication No.6c.

Warisno \& K. Dahana. (2010). Peluang Usaha dan Budidaya Cabai. PT Gramedia Pustaka Utama. Jakarta.

Wartapa, A., Effendi, Y., \& Sukadi. (2009). Pengaturan Jumlah Cabang Utama dan Penjarangan Buah Terhadap Hasil dan Mutu Benih Tomat Varietas Kaliurang. Jurnal Ilmu-ilmu Pertanian. Vol 5 (2) : 150-162.

Wasis, B., Mulyana, D., \& Winata, B. (2015). Pertumbuhan Semai Jabon(Anthocephalus cadamba) Pada Media Bekas Tambang Pasir Dengan Penambahan Sub Soil Dan Arang Tempurung Kelapa. Jurnal Silvikultur Tropika. Vol. 06 (2) : 93-100.

Wiguna, G (2013). Perbaikan Viabilitas dan Kualitas Fisik Benih Tomat Melalui pengaturan Lama Fermentasi dan Penggunaan NaOCL pada saat Pencucian Benih. Media Agro. Vol 2(2) : 68-76. 